\title{
Conceptualizing Waqf Insan on i-HDI (Islamic Human Development Index) Through Management Maqashid Syariah
}

\author{
Miftahul Huda ${ }^{1}$, Imam Haryadi ${ }^{2}$, Adib Susilo $^{3}$, Achmad Fajaruddin $^{4}$, Fadhila Sukur Indra $^{5}$ \\ \{miftahulhuda@unida.gontor.ac.id ${ }^{1}$, haryadi@unida.gontor.ac.id², adib.susilo27@gmail.com ${ }^{3}$ \} \\ University of Darussalam Gontor, Jl. Raya Siman Km. 6 Siman Ponorogo East Java 63471 ${ }^{1}$, \\ University of Darussalam Gontor, Jl. Raya Siman Km. 6 Siman Ponorogo East Java $63471^{2}$, University \\ of Darussalam Gontor, Jl. Raya Siman Km. 6 Siman Ponorogo East Java 63471³
}

\begin{abstract}
The conception of waqf insan as a reference for i-HDI can improve human development which is the welfare of Muslim society, including this we called the Islamic Man. Human Resources is the capital in national development. The method used in this study is a qualitative study which involving literature study and the main object of this study is to examine the application of Maqashid sharia as a reference to i-HDI in the concept of waqf insan referring to the basic principle of Islamic economic aim, namely Falah. With that, there is an effort to realize i-HDI (Islamic Human Development index) as a reference for measurement in achieving the level of human well-being by fulfilling basic needs so that people get happiness in the world and the hereafter. The reference measurement that proposed as Maqashid Sharia Index (MSI) which has been listed in Maqashid sharia which is maintained religion, soul, mind, descent (honour), and wealth. The five bases that can be referred to as absolute needs that must be fulfilled so that humans could reach Mashlahah.
\end{abstract}

Keywords: Waqf insan, i-HDI, mashlahah, maqashid syariah index.

\section{Introduction}

The term waqf is already familiar to the world society, especially in Indonesia which is a majority of Muslim people. However, literacy about waqf is still considered lacking, because some people still argue that waqf will always be related to wealth. Thus the matter will be associated with a property, treasure, worth, land, and holding, etc.

The historical context of Muslim has explained that the use of waqf is not a new thing, as developed by the al-Azhar educational institution in Egypt during the Fatimiyyah dynasty (Masehi $9^{\text {th }}$ century). Al-Azhar grew up and developed over waqf facilities. In Indonesia country, Islamic Modern Boarding School Darussalam Gontor is one example of an institution that uses waqf to developed human resources and finances the operations of its institution.[1]

Throughout Islamic history, waqf has a vital role in improving the welfare of Islamic society through education, economics, health, and culture. During the Abbasiyyah dynasty and Ottoman Empire, for example, waqf as one of Islamic philanthropy began to be used to finance the education dan research sectors, such as the construction of madrasah and the provision 
scholarships, as well as the establishment of libraries for research, lectures, and community teaching.[2]

The waqf insan (soul) will still refer to the objectives of Islamic law (Maqashid sharia) which is to realize Mashlahah and Mudharat. Resources for waqf include immovable objects, movable object, money, and services. The developing development trend is the level of economic growth as measured by the Human Development Index (HDI), which is seen from the average level of quality of human life in various region.

Various sizes are formed, but not all of them can be used as a standard size. The ultimate goal of development is the welfare society. Human is not only objects of development, but are possible and are expected to become subjects so that they can provide useful contributions to the progress of a region that is macro toward the progress of a country. The method used in this research is qualitative studies that involve library research, and the main object of this study is to review the application of Maqashid Syariah as a reference for i-HDI in the concept of the waqf insan.

\section{Waqf Insan}

As expressed by Azyumardi Azra, "Waqf is a private possession or asset in any form that has been put under an injunction from any form of a transaction including the sale, inheritance, Hibah (grant) and Wassiyyah (will), while its natural source (ain) remains intact and unchanged. From the Islamic point of view, endowment ownership is non-permanent because it has been entitled to Allah SWT to benefit all Muslim. " Therefore, waqf in this sense is eternal for the Ummah and the personal ownership of the waqf assets is returned to Allah. The results of the management of waqf are then used for the benefit of the ummah [4]

The next question appears, is the waqf only in the form of immovable assets or in the form of cash assets only? Is time, energy, thoughts can also be categorized as assets that can be waqf by someone? It is because waqf voluntarily has become part of the third sector of waqf in addition to visible assets. This waqf aims at how the waqf manager then exposes himself to give then up time, energy, thoughts in developing physical waqf assets to become bigger and more beneficial for the welfare of the people.[5]

The waqf model based on volunteers has been and is still being implemented in several waqf institutions in Indonesia, one of which is the Modern Darussalam Gontor Cottage. Gontor uses the term waqf himself for those who have vowed voluntarily to give up their time, energy, thoughts, even personal assets to manage waqf Gontor's.

Islamic Modern Boarding School Darussalam Gontor is an educational institution based on boarding schools, located in Ponorogo regency, East Java. This waqf-based boarding school has long been implementing the self waqf or waqf insan (soul) system. The primary basis for submitting waqf is sincerity. The first step is to hand over the lodge through waqf to an institution called the Waqf Agency. The surrender took place in 1985; the waqf institution obtained the authority to manage and develop the lodge according to the waqf pledge.

The idea of waqf is inspired by the existence of al-Azhar University in Egypt, which has extensive waqf land so that it can provide scholarships to an international student. Furthermore, the waqf is followed by provisions regarding the system and mechanism of the Muslim boarding school organization, regarding the limitations of right, authority, and obligation to management. It is expected so that Islamic Modern Boarding School Darussalam Gontor can continue to live and develop, even though the founder has left behind. 
The waqf insan practised in Islamic Modern Boarding School Darussalam Gontor refer to Maqashid sharia which is to bring Mashlahah. A form of service that is shown for Mashlahah and development. The position of waqf in the perspective of jurisprudence (fiqh) has two classifications:

1. Waqf insan is permissible and legal according to Abu Hanifah and Imam Malik, because waqf objects remain the property of wakif, while those that are donated or represented are only benefited that is the form of service and wakif energy for the mashlahah and development. Because the substance of waqf teachings does not merely lie in the maintenance of the objects (waqf), but so far more critical is the value of the benefit of the object for the public interest. The Hanafi Mazhab though also stated that the period of waqf must be forever and must not be limited by time.[6]

2. Unauthorized waqf insan are reviewed from the Syafi'i Mazhab and Hanbali Mazhab because the terms of the waqf property are wholly owned by wakif, whereas humans do not have ownership rights to them according to Syara'. It is because the act of waqf is aborting property rights by mean of Tabarru' since he pledged it and property that was represented when it belonged to Allah or public property. According to Ibn Siraj from Syafi'i Mazhab, the period of waqf may be limited by time and does not have to be forever.[6]

Islamic Modern Boarding School Darussalam Gontor develops waqf sources to include immovable objects, movable objects, money, and services. Trimurti ${ }^{1}$ As the head of the lodge formulated an exploratory and open waqf concept. In the waqf charter is not explicitly explained the fiqh themes referred to in the provisions of the sharia. Judging from the normative statement implies a message about the importance of preserving waqf.

The text in waqf charter included some mandates, first that the waqf institution must always obey and comply with the sharia provisions, secondly that the waqf should always a source of Islamic knowledge, Arabic, and general science, and fourth to keep and maintain the value and soul of the boarding school.

There are aims of the reason why the waqf in Gontor including self-waqf is held. They are to maintain the people's trust in Gontor; to continue to carry out an integrated education between religious and general education with a system that survives from the beginning to the present; to safeguard Islamic values from invaders and occupation; to develop waqf assets become more productive; and to be able to continue to support Gontor's Islamic Boarding School even though the founder of the lodge is already sustainable development. It is similar to that expressed by Mannan, that waqf must be built based on trust and must have five primary roles, that is safeguarding the ideology of Islam, maintaining and developing Islamic education, aimed at developing the welfare of the people, and finally maintaining the value of Islam from colonialism.[3]

Therefore the waqf insan base used in the study as a reference or example is waqf insan in Gontor. The waqf object of self is that it provides or organizes religious, social services in the form of religious education, socio-economic in the form of development of waqf business units or endowments, and other social activities aimed at providing general welfare to the people sincerely without expecting compensation. It is expected that the waqf insan model available at Gontor can be used as a benchmark for how Human Resources as the first capital of national welfare can achieve the expected aim to the maximum.

\footnotetext{
${ }^{1}$ Founder of Islamic Modern Boarding School Darussalam Gontor (K.H. Ahmad Sahal, K.H. Imam Zarkasyi, K.H. Zainuddin Fannani)
} 


\section{I-HDI (Islamic Human Development Index)}

Human resources is a necessary capital in national development. Therefore, the quality of human resources must be developed and directed goals. Human resources itself can be seen from two aspects quality dan quantity, quality aspects include the amount of available human resources, while quality aspects include being seen through the ability of human resources both physically a non-physically, that is intelligence and mentality in carrying out development. So that in the development process, the development of human resources is needed, because the quality of human resources without being supported by the right quantity will be a burden on the development of a nation.

According to the UNDP (United Nation Development programme), human development is a process of expanding choices for residents to build their lives that are considered valuable. Some things are essential so that people can feel a long and healthy life,

knowledgeable, and have access to the resources needed for a decent life. Human resources is a significant capital in national development, so the quality of human resources must be developed and directed to achieve the expected goals. The United Nation (UN) sets a measure of human development standards, that is the Human Development Index (HDI), which is measured by the quality of education, health, and economic levels (purchasing power).[7]

in particular, the human development index measure human development achievements in the number of essential components of quality of life.[8] to see the quality of human resources in Indonesia can refer to HDI.[9] Human development or improving the quality of human resources in development are significant in national development. Emphasis on the importance of increasing human resources in development is a necessity because the human quality in a region has a significant role in determining the success of managing the development of its territory.

The existence of HDI offered by the United National Development Program (UNDP) as one of the tools that can be used to measure the level of human development may be the most comprehensive indicator, but not fully compatible and sufficient to measure human development in an Islamic perspective. The underlying theory and concept for building HDI are based on Maqashid sharia. To measure the level of human development in a Muslim majority country, it would be more appropriate to use the Islamic Human Development Index (i-HDI), which is based on an Islamic perspective and concept.[7]

The quality of human resources must continue to be developed to achieve prosperous the aim. With that, there is an effort to realize i-HDI as a reference for measurement in achieving the level of human welfare by fulfilling a basic need.

I-HDI measure the achievement of the level of human welfare by fulfilling the basic so that humans can live life happily in the world and the hereafter (Falah achievement). Mashlahah according to Ghazali is the effort of every creature (human) in maintaining the purpose of Islamic law. Because by maintaining these five principles the achievement of the aim of humans in their life, is nothing but salvation in the world and the hereafter, by maintaining religion, soul, mind, descent (honour), and wealth, the aim will be realized.

\section{Maqashid Syariah Index (MSI)}

Understanding a complete of the Maqashid Sharia Index (MSI) taken from Maqashid sharia is understood as the ultimate aim of sharia with welfare and beneficial values. The Maqashid 
sharia, which is more detailed according to Ghazali, consists of five things, including maintaining religion, soul, mind, descent (honour), and wealth. So, whatever guarantees the fifth preservation is called Mashlahah and everything that escapes from it is called Mafsadah (damage). Maqashid sharia is an aim in life that is determined by Allah with all its laws that can bring goodness an benefit to humans both in the world and in the hereafter when carrying out it.

Maqashid Sharia Index (MSI) is understood as the ultimate aim of sharia which leads to welfare values and benefits. Maqashid sharia index was developed with three main factors, that is education, the creation of justice and the achievement of welfare, where the three factors are universal.[10]

Every containing an effort to maintain the five things this principle is called Mashlahah, and everyone that removes these five principles is Mashlahah and rejects it called Mafsadah.[11] if Maqashid sharia requires the achievement of a Mashlahah, then logically this concept also concerns avoiding what we often call Mafsadah (damage). Mafsadah is the opposite of Mashlahah. If Mashlahah wants to be achieved by Maqashid sharia, then Mafsadah mus be avoided.[12]

Table 1. five index dimension toward Maslahah

\begin{tabular}{cll}
\hline Development Goal & Dimension & Index Dimension \\
\hline \multirow{4}{*}{ Mashlahah } & Hifdzu Dien & Index Dien \\
& Hifdzu Nasfs & Index Nasf \\
& Hifdzu Aql & Index Aql \\
& Hifdzu Nasl & Index Nasl \\
& Hifdzu Maal & Index Maal \\
\hline
\end{tabular}

From the table it can be seen that the purpose of Islamic economic development is based on Mashlahah; for this reason, an index is represented from each dimension to measure the five dimensions. The five indexes are used to measure the five dimension of Maqashid sharia. The values of the five indices above will be assessed based on indicators that reflect each Maqashid.

Maslahah has different definitions of his conception, but the substance is the same, both from classical and contemporary scholars. But of all the definitions that have the same purpose and aim, that is prioritizing both individual and social welfare.

Measuring these five dimensions is formed by an index representing each of these dimensions, an index is formed which is purposed to measure the five dimension. The indicator offered to refer to idealism, soul, and philosophy of life and a system that still refers to the world treasure of the Islamic Boarding School. Have values, philosophy, an orientation which forms the basis for the formulation of the vision, mission and objective of the Islamic Modern Boarding School. It is the basis of the indicators offered.

Table 2. Holistic Welfare with the proposed indicator

\begin{tabular}{llll}
\hline Welfare & Dimension & Dimension index & Indicator \\
\hline & Hifdzu Dien & Index Dien & Islamization \\
& Hifdzu Nasfs & Index Nasf & Sincerity \\
& & Simplicity \\
& & Self Sufficiency
\end{tabular}




\begin{tabular}{ccll}
\hline Welfare & Dimension & Dimension index & Indicator \\
\hline & & & Islamic \\
& & & Brotherhood \\
& & Freedom \\
No material welfare & Hifdzu Aql & Index Aql & Sound Body \\
& & & Broad Knowledge \\
& & & Independent Mind \\
& & & Education \\
& Hifdzu Nasl & Index Nasl & Teaching \\
& & Regeneration \\
Material welfare & Hifdzu Maal & Index Maal & Family welfare \\
& & & Khizanatullah \\
& & & Building \\
\hline
\end{tabular}

The indicators offered in table 2, make a mini model of the implementation of waqf insan in i-HDI based on maqashid sharia management between the three interrelated and complementary things, maqashid sharia index will be more realistic in its application in developing human development in quality and accountability.

The concept of Islamic human development akes one have two aim at once without comparing between the two, that is the interests of the world and the hereafter. Planting the concept of waqf insan as an example of the application of i-HDI in increasing human development which is the welfare of Islamic societies, including this which we call the Islamic Man.

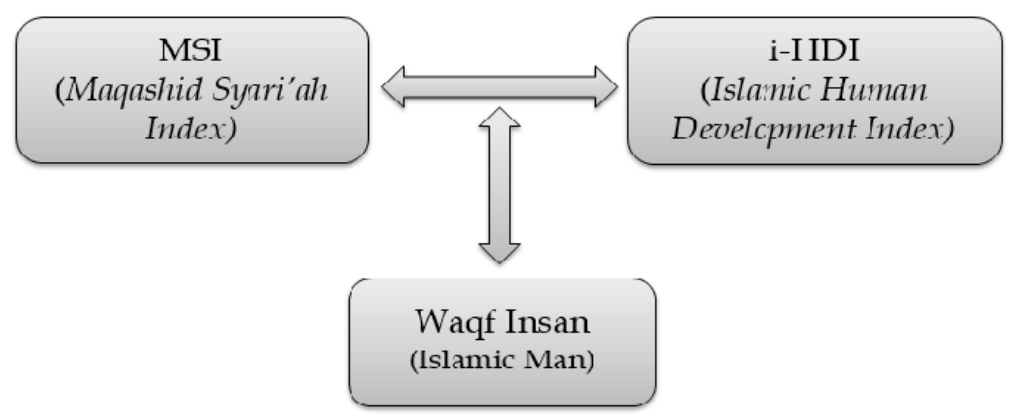

Fig. 1. the model waqf insan on i-HDI

The picture above shows that Maqashid Syariah Index (MSI) is a tool to measure and can be a reference in implementing the Islamic Human Development Index (i-HDI) with the indicators offered. Human endowments as an example of its implementation model will become a reference for the level of human development. The three images above will be interrelated and influence.

With the existence of this Islamic Man as an effort to prosper the people, the primary purpose of waqf can be achieved through the waqf insan of the Sustainable Development Goals with Maqashid Syari'ah as the basis of its measure. The SDGs themselves are the fundamental 
ethos of Maqashid Syari'ah, which is aimed at achieving a healthy life, good education, equality and equal opportunities to develop. In other words, waqf itself is the answer to the development of waqf required by Maqashid Syari'ah, namely the evolution of waqf in a global context to comprehensively address the welfare problems of the Ummah

The essence of human development is how a human being becomes perfect and by his nature. Islam sees the purpose of the creation of human beings as worship, meaning that humans will be responsible for all that is done in the world to the Creator, Allah, the desired happiness is the happiness of the world and the hereafter.

With the uniqueness of waqf insan, this human being can expand the meaning of the waqf itself. If someone wants to implement this type of waqf, then the size offered is Maqashid Syariah Index. When the fulfilment of MSI automatically creates human development that repeats values to Islam without putting aside world affairs, a balance will emerge in his life.

\section{Conclusion}

Waqf can be used as a means to empower the community to achieve Mashlahah; the waqf phenomenon of the soul still refers to the achievement of Mashlahah. The HDI (Human Development Index) benchmark is always associated with worldly welfare and overrides the factor of religiosity. The unique concept of waqf human (soul) can be an example of an application in the measurement of i-HDI (Islamic Human Development Index).

Maqashid Sharia Index (MSI) is a model that will be used in i-HDI, with the development of indicators in it. Darussalam Gontor Islamic Modern Boarding School is a pilot project in the application of MSI-based i-HDI with indicators of human development.

Waqf is very synonymous with wealth, but there is a uniqueness in the waqf is waqf insan, which is the purpose of the Mashlahah of obtaining falah (world and hereafter welfare). Planting the concept of waqf insan as an example of the application of i-HDI in enhancing human development that is Islamic society's welfare, this term we call the Islamic Man. The quality of human resources must continue to be developed to achieve a prosperous aim. With that, efforts have been made to realize i-HDI as a reference for measurement in achieving the level of human welfare by fulfilling basic needs.

\section{Acknowledgements}

We thank Islamic Boarding School Darussalam Gontor, who has inspired this research and provided insight into the management of waqf property, especially the application of the waqf insan (human) that has been genuinely realized until now.

\section{References}

[1] A. S. Zarkasyih, Manajemen Pesantren Pengalaman Pondok Modern. Ponorogo: Trimurti Press, 2005.

[2] A. Azra, Jaringan Ulama Timur Tengah dan Kepulauan Nusantara Abad XVII dan XVIII Akar Pembaharuan Islam Indonesia. Jakarta: Kencana, 2004.

[3] M. A. Mannan, “Tje role of Waqf in Improving the Ummah Welfare," Medan, 2005.

[4] R. Masruki and Z. Shafii, "The Development of Waqf Accounting in Enhancing Accountability," Middle-East J. Sci. Res. 13, 2013. 
[5] I. N. Muhammad, "Waqf Based Philantrophy: A Difination ad Obstacles to Waqf Knowladge Acquisition in North-Western Nigeri," Nigeria, 2016.

[6] W. az Zuhaili, al-Fiqh al-Islam wa Adillatuhu. Damaskus: Dar al Fikr al Mu'ashir, 2008.

[7] M. M. Septiarini, “Analisis i-HDI (Islamic Human Development Index) di Jawa Timur,” J. Ekon. Syariah Teor. dan Terap., vol. 4, p. 381, 2017.

[8] M. L. Jhingan, Ekonomi Pembangunan Islam. Jakarta: Kencana, 2015.

[9] D. Huda, Nurul, Ekonomi Pembangunan Islam. Jakarta: Kencana, 2015.

[10] M. Omar and Dzuljastri, "The Performance Measure of Islamic Banking Based on The maqashid Framework," Malaysia, 2008.

[11] A. Ghazali, al Mustashfa Min 'Ilm al Ushul. Beirut: Darul al Fikri.

[12] I. Y. Fauzia and A. K. Riyadi, Prinsip-Prinsip Ekonomi Islam: Prespektif Maqashid Syariah, Pertama. Jakarta: Kencana, 2015. 